\title{
Racial Threat and Opposition to the Re-Enfranchisement of Ex-Felons
}

\author{
Ted Chiricos ${ }^{1, *}$, Kathy Padgett, ${ }^{1, \#}$, Jake Bratton ${ }^{1, \#}$, Justin T. Pickett ${ }^{2, \#}$ and Marc Gertz ${ }^{1, \#}$ \\ ${ }^{1}$ College of Criminology and Criminal Justice, Florida State University, USA \\ ${ }^{2}$ School of Criminal Justice, University at Albany, SUNY, USA
}

\begin{abstract}
Prior research demonstrates that racial threat is related to the time, place and severity of disenfranchisement laws for ex-felons. This study builds on that work by examining whether perceived racial threat helps to account for public opposition to the abolition of disenfranchisement policies. To do this, we draw on interview data from a survey of 1,575 Florida adults randomly sampled in 2005. Perceived racial composition of neighborhood and the perceived involvement of blacks in several crimes - the racial typification of crime - are our measures of perceived racial threat. Perceived racial composition is unrelated to opposition to re-enfranchisement of ex-felons. But the racial typification of crime significantly predicts that opposition, independent of the effects of general punitiveness, conservatism, and other predictors. Among white respondents that relationship is strongest for those who are liberal/moderate and generally less punitive and is not effected by varying levels of racial threat measured at macro-social levels.
\end{abstract}

Keywords: Racial typification, disenfranchisement, voting rights, felon, public opinion, punitiveness.

Losing the right to vote is one of the most important "collateral consequences" (Mauer and Chesney-Lind 2002) of being convicted of a felony in the United States. This country is unique among industrial democracies in denying that right to millions of citizens who are not in prison and have completed the terms of their criminal sentence (Manza and Uggen 2006:41). Eight states categorically revoke the right to vote for all ex-felons and five additional states bar some ex-felons from the franchise (Pinaire, Heumann, and Bilotta 2003:1522-23) ${ }^{1}$. Scholars estimate that more than two million convicted felons who have completed their sentence are disenfranchised and almost one million of them reside in Florida, which is the site of the present research (Manza and Uggen 2006:77-90).

The consequences of felon disenfranchisement go beyond the denial of civic reintegration and the reinforcement of criminal stigma for individuals. They include as well, exclusion from the political process of extraordinary numbers of African Americans. As Behrens, Uggen and Manza (2003) have noted, felon disenfranchisement laws are "race neutral" on their face, but because of the disproportionate numbers of African Americans convicted of felonies in the United

*Address corresponding to this author at the College of Criminology and Criminal Justice, Florida State University, 634 West Call Street, Tallahassee, FL 32306-1127, USA; Tel: 850-644-7371; Fax: 850-644-9614;

E-mail: tchiricos@fsu.edu

\#Co-Authors E-mails: kpadgett@frontier.com, jbratton@jakebratton.com, jpickett@albany.com, mgertz@fsu.edu

\footnotetext{
${ }^{1}$ Some states have provisions in place for the eventual restoration of civil rights, but these often have time qualifications and involve frequently cumbersome and poorly publicized procedures for doing so (Hull 2006; Pinaire et al. 2003).
}

States, the racial consequences for the electoral process are substantial. It has been estimated that approximately 8.5 percent of voting age African Americans are denied the right to vote, compared with an overall national disenfranchisement rate of 2.4 percent. Of the almost 2 million African Americans excluded from voting, more than 600,000 have completed the terms of their sentence, and over 200,000 of the latter live in Florida (Manza and Uggen 2006:250-51). It has been shown that if ex-felons in Florida had been re-enfranchised at the time of the 2000 presidential election, the outcome in that state and in the Electoral College would have been easily changed (Uggen and Manza 2002:792) ${ }^{2}$.

The enactment of legal provisions that result in the exclusion of African Americans from voting has a long history in the United States. The institution of barriers such as the poll tax, literacy tests, "grandfather" clauses and white-only primaries, were obvious attempts to circumvent the $15^{\text {th }}$ Amendment to the Constitution, passed in 1870 shortly after the Civil War, which prohibited denial of suffrage on account of race, color or previous condition of servitude. And a common argument in support of those exclusions made explicit reference to racial disparities in incarceration which were presumed as "evidence that African Americans were unworthy of assuming the full rights and duties of citizenship" (Uggen, Manza, and Behrens 2003:51).

\footnotetext{
${ }^{2}$ Uggen and Manza (2006) base their analysis of the potential effects on electoral outcomes if disenfranchised ex-felons had been allowed to vote on carefully developed models estimating the likelihood of turnout and voter choice (pp. 783-89).
}

(C) 2012 Lifescience Global 
But felon disenfranchisement laws in many states pre-date the $15^{\text {th }}$ Amendment and there is substantial evidence that race and the potential threat of newly enfranchised African Americans played a central role in their enactment and subsequent modification. Nineteen states, including most of the deep-South states passed such laws between 1865 and 1899 (Manza and Uggen 2006:55). The racial dimension in this process is well documented by the historical/empirical analysis developed by Behrens et al. (2003; see also Manza and Uggen 2006:41-68). They found that the timing of the initial passage of those laws was strongly influenced by several measures of "racial threat," including the percent of a state's prison population that was non-white. Their analysis also showed that "states with fewer African American prisoners ... have been quickest to to restore voting rights to former felons" (Behrens et al. 2003:594). Preuhs (2001) has similarly demonstrated that percent minority is a strong predictor of the current severity of states' felon disenfranchisement laws, though there is some evidence that this relationship is curvilinear (p. 742).

Laws restricting the right to vote of felons and exfelons have been described as giving expression to "a conscious attempt to dilute African American voting strength" (Uggen et al. 2003:50) and in the process diminish the threat that blacks could pose to white political power. It is in this context that Uggen and his colleagues (2003:50) conclude that "the extension of . . . racial threat theories to felon disenfranchisement is straightforward." As such, the linkage of voting exclusion and racial threat builds upon a substantial theoretical and empirical foundation that has linked racial threat to various measures of social control.

The present research further extends the application of racial threat to the understanding of felon disenfranchisement policy. We do so at the level of public opinion. Specifically, we make use of survey data $(\mathrm{N}=1,575)$ from a state-wide random sample of Florida adults taken in 2005. We examine the extent to which two measures of perceived racial threat help to explain popular opposition to the restoration of voting rights upon the completion of one's sentence. This is the first attempt that we know of to use a multi-variate approach to account for public opinion on this issue.

\section{RACIAL THREAT AND SOCIAL CONTROL}

What is now termed "racial threat" in the study of social control (Pickett et al. 2012; Stolzenberg, D'Alessio, and Eitle 2004; Ulmer and Johnson 2004) is an emergent concept that has its roots in the "power threat" perspective developed initially by Blalock (1967). In that perspective, it was hypothesized that a growing "minority" population could pose economic, political and status threats to a white majority and thus provide a potential basis for the mobilization of various kinds of controlling responses. For Blalock (1967), these responses included political discrimination (e.g. voting exclusions), symbolic segregation (e.g. Jim Crow laws) and what were described as threat oriented ideologies. The latter were described as "exaggerated beliefs concerning the threatening aspects of the Negro personality ... [ [which] function to rally white sentiment and justify violent or extreme forms of social control" ( $p$. 167). It should be noted that Blalock clearly recognized that "the so-called 'minority' may be in a numerical majority" and still retain "subordinate" status (1967:145). He was also careful to specify that very often threat could be produced by "an increase in minority presence" independent from actual levels of racial composition (Blalock, 1967:154).

Over time, the putative threat posed by minorities, and more specifically by blacks, has been gradually shifted from the political and economic dimensions emphasized by Blalock (1967) to the specific threat of crime, which is similarly hypothesized to have mobilizing influence on various forms of social control. Liska (1992) called attention to "social threats" potentially posed by large numbers of minorities especially blacks - to the "interests of authorities." Social threat was hypothesized to influence the likelihood of social controls that range from being fatal (lynching, executions, police use of deadly force) to the exercise of coercion (police department size and funding, incarceration) to those that are presumably beneficent (welfare expansion; mental health diagnoses and treatment). An extensive body of research has developed to assess those hypotheses.

Implicit in the social threat approach is the assumption that the relative size of the African American population in a given place, is related to the perceived threat of crime, which then has consequences for the mobilization of coercive controls. Liska and Chamlin (1984) were one of the earliest to articulate the implicit "logic" of this position, by noting that "the threat hypothesis . . . suggests that a high percentage of nonwhites produced an emergent property, 'perceived threat of crime,"' which presumably accounts for various social control impulses (p. 384). A number of researchers have shown that the actual and perceived racial composition of place is related to 
threat based responses such as the fear of crime (Skogan 1995; Taylor and Covington 1993), the willingness to report crime to the police (Warner 1992), and the perceived risk of victimization (Chiricos, McEntire, and Gertz 2001; Pickett et al. 2012). Thus, following the lead of Crawford et al. (1998), who were the first to characterize this threat/control issue as "racial threat," more recent observers have begun to pose the discussion of threat in race and crime specific terms. The racial threat hypothesis has since been applied to a variety of social control outcomes, including sentencing decisions (Britt 2000; Ulmer and Johnson 2004) arrests for violent crime (Stolzenberg et al. 2004) and variations in felon disenfranchisement statutes (Behrens et al. 2003; Uggen et al. 2003).

As noted, racial threat has generally been operationalized in terms that assume large and/or proximate concentrations of minorities increase the putative threat of crime. Measuring the relationship between perceived or actual racial composition of where people live and various control related outcomes reflects that assumption. But Chiricos, Welch and Gertz (2004:380) have argued that racial threat "may be activated not only by the residential proximity of racial minorities but by the conflation of race and crime that exists in the minds of many, regardless of where they live." They suggest that the "racial typification of crime" - or the extent to which crime is characterized in racial terms - may actually be a more direct measure of racial threat than racial composition and residential proximity. Indeed, the relevance of the latter for threat actually presumes that crime is typified in racial terms (Pickett et al. 2012).

In addition, it could be argued that the perceived racial composition of place and the racial typification of crime may be measuring slightly different elements of threat. Specifically, the perception that large numbers of blacks live nearby could induce threat related responses such as the fear of crime or the willingness to report crimes to the police because an individual feels personally threatened. However, the perception that blacks are disproportionately involved in crime, while not necessarily threatening to someone who lives far removed from minorities, could still generate a perception of threat to the community at large that might be the basis for supporting harsh punitive measures toward criminals or opposition to the reenfranchisement of ex-felons. Thus, for those living in close proximity to racial minorities, perceived racial composition of place would only be threatening if there was a perceived a link between minorities and crime (racial typification), but for those living in more racially segregated environments, the racial typification of crime could also produce a threat that is felt at a broader, non-personal level.

The racial typification of crime is nothing new in American culture (Hawkins 1995; Russell 1998), but it has been argued that the link of crime and race became stronger and more commonly expressed in the 1980s and 1990s (Barlow 1998). Some point to the political advertisements by presidential candidate George H.W. Bush in 1988 that made repeated use of the likeness of Willie Horton, an African American convicted of murder and mistakenly granted furloughs from prison in his opponent's home state, as a pivotal moment in mainstreaming the racial typification of crime (Jamieson 1992; Mendelberg 1997). That typification is so well established that in much discourse about crime "it is unnecessary to speak directly of race because talking about crime is talking about race" (Barlow 1998:151). In this regard, Jerome Miller, former director of juvenile corrections in Massachusetts and Pennsylvania, has observed:

There are certain code words that allow you never to have to say 'race,' but everybody knows that's what you mean and 'crime' is one of those ... So when we talk about locking up more and more people, what we are really talking about is locking up more and more black men (Szykowny 1994:11).

The present research examines whether the racial typification of crime is a significant predictor of popular opposition to the restoration of voting rights for convicted felons who have completed the terms of their sentence. We also assess the relevance of an alternative measure of racial threat - the perceived racial composition of place - as a predictor of this unique measure of punitive attitudes toward criminals.

\section{PRIOR RESEARCH: PUBLIC OPINION AND EX- FELON RE-ENFRANCHISEMENT}

There is no previous research examining the specific questions we address here. However there have been three recent public opinion surveys concerning support for the re-enfranchisement of exfelons that provide important descriptive data on this issue. The first was published by Pinaire et al. (2003) and was based on a national survey of 503 adults conducted in 2001 by The Center for Survey Research and Analysis at the University of Connecticut. That 
survey found that 71.8 percent of respondents believed that felons should only be disenfranchised while they are serving their sentence in prison, on probation or parole. Another 9.9 percent felt that felons should never lose their voting rights (Pinaire et al. 2003:1536). Support for giving convicted felons the right to vote "at some point" was slightly lower among white as compared to black and Hispanic respondents, showed little difference by gender and education, but was significantly higher for Democrats than for Republicans (Pinaire et al. 2003:1538-1544).

In a second study, Heumann and colleagues (2005) used a non-probability sampling procedure to select several Rutgers University employees and students to engage in focus group discussions of disenfranchisement policy. This research similarly found high levels of public support for felon reenfranchisement. In addition, the investigation yielded evidence suggesting that many members of the public support restoring voting rights to ex-felons because they perceive negligible crime control benefit in voting prohibitions.

Manza, Brooks, and Uggen (2004) presented results of a 2002 survey conducted by Harris Interactive that interviewed a national sample of 1,000 adults. They were specifically concerned with how attitudes toward the enfranchisement of felons varied by level of correctional supervision and by type of crime. Of particular relevance to the present study, Manza and his colleagues estimated levels of support for the re-enfranchisement of ex-felons operationalized as people "convicted of a crime who have served their entire sentence, and are now living in the community." Their methodology alternated "convicted of a crime" with conviction for the illegal trading of stocks, violent crime, and sex offenses for randomly chosen segments of their sample. Levels of support for restoring the right to vote varied by crime type with 80 percent supporting re-enfranchisement of those convicted of an unspecified crime, 66 percent for violent offenders, 63 percent for illegal stock traders and 31 percent for sex offenders. The authors concluded that their data offer "little support for the assumption that the American public consistently supports the disenfranchisement of felons and exfelons who are not currently incarcerated" (Manza et al. 2004:283).

\section{PRIOR RESEARCH: RACIAL ATTITUDES AND PUNITIVENESS}

Given the absence of prior studies specifically investigating the relationship between racial beliefs and public views about felon re-enfranchisement, our focus in this section will be on a second body of literature that is germane to the present inquiry. We examine what is known about the relevance of various racial attitudes for the support of punitive policies. The research in this area consistently shows that those who have negative racial perceptions are generally more punitive toward criminals-though only a few studies have looked at the racial typification of crime as the negative racial perception. For example, national survey data have been used to show that racial prejudice among whites is predictive of support for harsh criminal punishments and support for the death penalty (Barkan and Cohn 1994; Cohn, Barkan, and Halteman 1991; Johnson 2001; Soss, Langbein, and Metelko 2003; Unnever and Cullen 2010). One recent study of this issue was conducted by Unnever and Cullen (2007) using 2000 National Election Survey interviews with 1,555 adults. They found that independent of the effects of religiosity, political orientation, authoritarianism, social class, media influence and perceptions of crime, two measures of what they termed "racism" were significant predictors of support for the death penalty.

Alternative approaches to the link between negative racial attitudes and punitiveness are illustrated by Rossi and Berk (1997) who provided crime vignettes to a national random sample and asked respondents to indicate an appropriate punishment for each. They also asked respondents whether they thought minorities had too few or too many "civil rights." With controls for demographics, region, criminal justice contact and other attitudes, the belief that minorities had too many civil rights was associated with harsher penalties for all crimes and greater support for the death penalty. In addition, Lieber and Woodrick (1997) asked juvenile court personnel about their perception of racial differences such as whether black juveniles had more negative attitudes and a lesser willingness to acknowledge guilt than juveniles who were not black. Belief in racial differences predicted support for the use of the death penalty for juveniles but was not related to support for stricter courts or a desire for harsher punishment in relation to juvenile offenders generally.

Barkan and Cohn (2005) have extended this type of analysis to support for spending more money to fight crime. The data were generated by the 2000 General Social Survey which included questions related to what they termed racial stereotyping and prejudice for 400 adults. Stereotyping was in terms of violence and was measured by responses to a question asking how violent-on a scale of one to seven-various groups 
were perceived to be. The groups included whites, Jews, blacks, Asian Americans, and Hispanic Americans. Anti-black prejudice was indicated by a combined scale that measured both aversion to contact with African Americans and willingness to attribute negative traits to African Americans. Controlling for a variety of factors that sometimes predict punitiveness, the authors found that stereotyping blacks as violent significantly increased respondent willingness to spend more money to deal with crime and that this relationship was confined to those who were more prejudiced (Barkan and Cohn, 2005:309-10).

Whereas Barkan and Cohn (2005) examined a racial perception that they called the stereotyping of blacks as violent, Chiricos et al. (2004) studied an analogous and slightly broader perception - the racial typification of crime and its relationship to punitive attitudes. That study used survey data from a national random sample and asked respondents to estimate the percentage of violent crimes, burglaries and armed robberies that were committed by blacks, whites and Hispanics. The percent linked to blacks was the measure of the racial typification of crime. Controlling for other predictors of punitiveness, including political conservatism, fear of crime and racial prejudice, the study found that support for an index of punitive measures that included the use of chain gangs, more executions, the use of the death penalty for juveniles, etc. was significantly higher for those who typified crime in racial terms.

Using a similar approach to measuring racial typification, but focusing specifically on youth crime, Pickett and Chiricos (2012) have recently demonstrated that among whites, typifying delinquency as a black phenomenon is associated with greater support for punitive youth justice policies and lower minimum ages for transferring juveniles to adult courts. By contrast, however, Unnever and Cullen (2012) found that endorsement of the stereotype of blacks as violent was not related to whites' preferences about the death penalty in 2000. They suggested that the strength of that relationship may have weakened over the course of the 1990s in response to declines in criminal offending and a presumed reduction in racialized discourse about crime.

Importantly, in Chiricos and colleagues' study (2004), the relationship between racial typification and punitiveness only held for whites who were not southern, less prejudiced and for whom concern about crime was relatively low. The authors thus concluded that in contexts where punitiveness is generally higher to begin with (southern, prejudiced, high crime concern) something of a "ceiling effect" may be in play that mitigates the possible effect of racial typification ( $p$. 376).

\section{EX-FELON DISENFRANCHISEMENT IN FLORIDA}

Manza and Uggen (2006:90) have observed that "Florida is 'ground zero' for discussing ex-felon disenfranchisement," and the issue has received substantial media and political attention in the state. In twelve months prior to and three months during which our survey was done on ex-felon voting rights, the Miami Herald, St. Petersburg Times, Orlando Sentinel, Tampa Tribune and South Florida Sun Sentinel (Palm Beach, West Palm Beach), with a combined circulation of 1.8 million, published a total of 666 stories on the topic of felon voting rights. An additional 81 stories were carried by the much smaller Tallahassee Democrat, which is published in the state capital.

For most ex-felons in Florida, the restoration of voting rights requires a formal application to the state's Board of Clemency, which is chaired by the governor. Until recent reforms requiring that the Department of Corrections provide information about the process, most ex-felons were unaware that the process even existed or how to initiate an application (Hull 2006:40). More than sixty percent of applications are summarily rejected as "ineligible" without a hearing, most often because of outstanding unpaid court fees or restitution requirements (Maza and Uggen 2006:93). The Clemency Board meets four times a year and hears, at most, 200 cases annually, with a rejection rate of 85 percent during the Jeb Bush years (Hull 2006:41).

Like poll taxes, literacy tests and "grandfather" clauses of an earlier era, the disenfranchisement of exfelons in Florida, and the outcome of the process for restoring voting rights are not race-neutral in their consequences. The disenfranchisement rate for African Americans of voting age in Florida is 19 percent, or more than double the overall rate for the state (Manza and Uggen 2006:92). A study of 1,217 clemency application case files revealed that compared to those convicted of felonies in Florida, African Americans, along with women and those who are younger are significantly under-represented among those who apply to the Clemency Board for the restoration of their civil rights. African Americans are not only less likely to apply for clemency but they are "more likely to have their applications returned as 'ineligible' because they owe money to the state and less likely to have their 
voting rights restored than whites" if they get to the point of a hearing (Manza and Uggen 2006:93-4).

The Florida Cabinet, which serves as the state's Clemency Board, voted in April of 2007 to allow for the automatic restoration of voting rights for selected exfelons. Those eligible for automatic restoration included individuals completing the terms of their sentence after April 5, 2007 with no pending criminal charges or outstanding victim restitution liabilities and whose criminal record does not qualify them as an habitual violent offender, violent career criminal or sexual predator (Crist 2007). However in March of 2011, a newly reconstituted Florida Clemency Board chaired by Governor Scott, established more restrictive rules for re-enfranchisement. Individuals convicted of nonviolent felonies must wait five years after completion of sentence and payment of restitution before becoming eligible to apply for restoration of voting rights. Those convicted of violent felonies face a seven year waiting period (Graham, 2011).

In short, given the dynamic status of disenfranchisement policy in Florida and the large number of residents of that state who are currently prohibited from voting due to prior felony convictions, an assessment of Floridians' views about the reenfranchisement of ex-felons seems especially important.

\section{RESEARCH HYPOTHESES}

Based on our discussion of racial threat as a conceptual issue that has been linked to disenfranchisement policy (Behrens et al. 2003; Preuhs 2001) and our review of the empirical evidence relating punitiveness to racial beliefs, we can reasonably formulate several hypotheses that will direct our analysis.

$\mathrm{H1}$ : Opposition to the re-enfranchisement of ex-felons will be higher for those who more strongly typify crime in racial terms, when controlling for other factors that generally relate to increased punitiveness toward criminals.

$\mathrm{H} 2$ : The relationship between opposition to re-enfranchisement of ex-felons and the racial typification of crime will be stronger for white respondents than for those who are either black or Hispanic.

H3: The relationship between opposition to re-enfranchisement of ex-felons and the racial typification of crime will be strongest in those individual level contexts that are generally associated with less opposition to re-enfranchisement.

H4: The relationship between opposition to re-enfranchisement of ex-felons and the racial typification of crime will be strongest in those social contexts where objective indicators of racial threat (\% black, and \% prison admissions involving blacks) are highest.

\section{RESEARCH METHODOLOGY}

The data used to address the hypotheses listed previously are from a survey of 1,575 adult residents of the state of Florida, who were selected by random digit dialing and responded to a telephone survey conducted between January and April, $2005^{3}$. The final sample demographics, as compared to 2005 census estimates in parentheses, are: female, $59 \%$ (52\%); black, $7 \%$ (15\%); Hispanic, 8\% (19\%); mean age, 53 (48); mean years of formal education, 14 (14). The overrepresentation of females, whites and respondents who are older is not uncommon in telephone surveys using random digit dial (Lavrakas 1993).

\section{Dependent Variable: Opposition to the Re- Enfranchisement of Ex-Felons}

Opposition to the re-enfranchisement of ex-felons after they have completed the terms of their sentence is indicated by responses to a series of questions replicating those used by Manza et al. (2004). Survey participants were first asked to respond to the following statement: "People convicted of a crime who served their entire sentence and are now living in the community should have the right to vote." Responses were dichotomized with "disagree" and "strongly disagree" coded as 1. "Agree" and "strongly agree" were coded as 0 . Three subsequent statements replaced "a crime" with "the illegal trading of stocks," "a violent crime" and "a sex offense." Each crime type is treated as a separate dependent variable because, as Manza et al. (2004) showed and our own data confirm,

\footnotetext{
${ }^{3}$ The survey was conducted by The Research Network, Inc., a public opinion polling firm in Tallahassee, Florida. A modified two-stage Mitofsky-Waksburg sampling design was used to enhance productivity. Using the definition recommended by the American Association of Public Opinion Research (2008) a 39 percent response rate was achieved. Ninety-six percent of all surveys initiated were completed.
} 
support for enfranchisement clearly varies by specific crime $^{4}$.

In this sample of Florida respondents, 27 percent opposed re-enfranchisement for felons generally, 31 percent for those convicted of illegal stock trading, 50 percent for violent offenders and 51 percent for sex offenders. Compared to the national sample surveyed by Manza et al. (2004) these results show Floridians to be harsher in this regard for felons in general and for violent offenders, but somewhat less harsh in terms of stock traders and sex offenders.

\section{Independent Variables: Perceived Racial Threat}

Our principal indicator of perceived racial threat is the racial typification of crime. It combines responses to three questions that ask:

If you think about crime and criminals, what percent of criminals who commit violent crime in the country are black?

When you think about people who break into homes and businesses when no one is there, what percent would you say are black?

When you think about people who rob other people at gunpoint, what percent do you think are black?

Respondents were also asked to estimate the percent involved in each crime that were white or Hispanic. An additive index (alpha = .89) combined the percent black from each of the three crime specific questions. Scores on that index could range from 0 300 .

It should be noted that as we conceptualize racial typification of crime, it is not a normative concept (Pickett et al. 2012). The issue is not whether respondents over-estimate, under-estimate or accurately estimate the involvement of African Americans in crime. It is a straightforward empirical perception of how much crime is perceived to involve black offenders (Pickett et al. 2012). It is the same as

\footnotetext{
${ }^{4}$ These items, modeled directly from survey questions used by Manza et al. (2004) in their study of public attitudes toward felon disenfranchisement, do not specify conviction for a "felony." The authors of the earlier survey did not indicate why they worded their items without reference to felonies. We do not because we want to be consistent with the earlier survey, and because to do so would introduce an unwieldy and time consuming definitional clarification to the survey that would likely be irrelevant to most respondents.
}

when researchers equate racial threat with actual or perceived numbers of African Americans and the greater the number, the greater the presumed level of threat. In this case, the more crime is associated with race, however accurately or inaccurately, the more perceived racial threat there may be.

That said, it is interesting-though not consequential in terms of our concerns-that respondent estimates substantially exaggerate black involvement in violent crime and burglaries but are close to official estimates for robbery. Specifically, the mean respondent perception of black involvement in violent crime is 46.2 percent, which compares to victim survey data that puts black involvement in completed violent crimes during 2004 at 18.5 percent (U.S. Department of Justice 2006). Respondents thought blacks were responsible for 43.2 percent of burglaries, but arrest data ${ }^{5}$ for 2004 show only 27 percent of those arrested for burglaries were black (U.S. Department of Justice 2005). Finally, our survey estimate attributed 45.3 percent of robberies to black offenders compared to 43.7 percent who were so identified by victims (U.S. Department of Justice 2006).

A second measure of racial threat included in our analysis is perceived racial composition of neighborhood. As noted earlier, perceived racial composition of place-measured as perceived percent African-American, black, or non-white-has been used as a measure of racial threat in research on the fear of crime (Skogan 1995; Taylor and Covington 1993), the willingness to report crime to the police (Warner 1992), and the perceived risk of victimization (Chiricos et al. 2001; Pickett et al. 2012). Here, perceived racial composition is indicated by responses to the question: "If you think about your neighborhood and the people living within a mile of your house, what percent of those people would you say are white, African American, Hispanic?" Percent estimated as being African American is our second measure of racial threat.

\section{Control Variables}

Also included in the models estimating opposition to the re-enfranchisement of ex-felons are a number of control variables, all of which are listed in Table 1, along with their associated descriptive statistics. The first is a general index of punitiveness toward criminals

\footnotetext{
${ }^{5}$ Victim surveys are more proximate to crime than arrests, but do not show the racial identity of offenders for non-violent crimes such as burglary, and so arrest is the best estimate of race specific involvement for that crime.
} 
(alpha $=.66$ which used principal components factor analysis to create factor weighted scores reflecting levels of respondent support (0-10) for five punitive measures relating to crime. These included making sentences more severe, deploying more police, limiting death sentence appeals, using chain gangs and restricting recreational opportunities for prisoners. Because opposition to the restoration of voting rights is a specific kind of punitiveness toward a particular group of criminals-those with a completed sentence and living in the community-we want to estimate the effect of racial threat on that measure of punitiveness, independent of the effects of any general disposition to support retributive crime policies.

A second set of control variables reflects the socio-demographic characteristics of respondents and includes age, race, Hispanic ethnicity, sex, education and income levels. Based on prior research dealing with punitiveness toward criminals, we expect that older persons will be more punitive (Manza et al. 2004), as will white respondents compared to their black and Hispanic counterparts (Blumstein and Cohen 1980; Cohn et al. 1991; Rossi and Berk 1997). Prior research assessing the effects of sex, education, and income are less consistent and appear to be conditional upon the specific measure of punitiveness being used (Blumstein and Cohen 1980; Grasmick and McGill 1994; Miller, Rossi, and Simpson 1991; Rossi and Berk 1997; Sandys and McGarrell 1995).

A third set of control variables included in our models has to do with beliefs and values found to be associated with punitive attitudes. The first, is selfidentified conservatism, which is measured dichotomously, with moderate and liberal combined as reference. We expect individuals who characterize themselves as politically conservative to be more punitive when it comes to the restoration of voting rights (Barkan and Cohn 1994; Langworthy and Whitehead 1986; Sandys and McGarrell 1995). Religious fundamentalism is a binary indicator of

Table 1: Descriptive Statistics and Pearson-r Correlation with Dependent Variables

\begin{tabular}{|c|c|c|c|c|c|c|}
\hline & Mean & S.D. & $\begin{array}{l}\text { Any Felony } \\
\text { Offender }\end{array}$ & $\begin{array}{l}\text { Illegal Trading } \\
\text { Offender }\end{array}$ & $\begin{array}{l}\text { Violent } \\
\text { Offender }\end{array}$ & $\begin{array}{l}\text { Sex } \\
\text { Offender }\end{array}$ \\
\hline \multicolumn{7}{|l|}{ Dependent Variables } \\
\hline \multicolumn{7}{|l|}{ Support for not restoring right to vote } \\
\hline Any felony offender & 0.27 & 0.45 & & & & \\
\hline Illegal stock trading offender & 0.31 & 0.46 & & & & \\
\hline Violent offender & 0.50 & 0.50 & & & & \\
\hline Sex offender & 0.51 & 0.50 & & & & \\
\hline \multicolumn{7}{|l|}{ Independent Variables } \\
\hline Racial typification of crime (index) & 135.22 & 46.54 & $.12^{* * *}$ & $.06^{*}$ & $.12^{* * *}$ & $.09^{* * *}$ \\
\hline $\begin{array}{l}\text { Perceived racial composition of } \\
\text { neighborhood (percent black) }\end{array}$ & 15.62 & 19.94 & -.04 & -.04 & $-.06^{*}$ & $-.07^{*}$ \\
\hline Punitiveness Index & 3.0 & 1.0 & $.27^{* * *}$ & $.22^{*+*}$ & $.28^{*+*}$ & $.24^{* * *}$ \\
\hline Age & 53.3 & 17.1 & $.11^{* * *}$ & .03 & $.07^{* *}$ & .01 \\
\hline \multicolumn{7}{|l|}{ Race/Ethnicity } \\
\hline White & 0.78 & 0.41 & $.05^{*}$ & .04 & $.08^{* *}$ & $.06^{*}$ \\
\hline Black & 0.07 & 0.25 & $-.07^{* *}$ & $-.07^{* *}$ & $-.07^{* *}$ & $-.08^{* *}$ \\
\hline Hispanic & 0.27 & 0.27 & -.01 & -.01 & -.04 & -.02 \\
\hline Education (years completed) & 14.2 & 2.7 & -.02 & $-.07^{* *}$ & -.03 & $-.09^{* * *}$ \\
\hline Female & 0.6 & 0.5 & .03 & .02 & $.05^{*}$ & .03 \\
\hline Income & 54,752 & 28,505 & $<.01$ & $<-.01$ & .01 & -.01 \\
\hline Unsafe & 0.16 & 0.37 & -.02 & $<-.01$ & -.01 & .02 \\
\hline Political conservativism & 0.37 & 0.48 & $.15^{* * *}$ & $.10^{* * *}$ & $.15^{* * *}$ & $.13^{* * *}$ \\
\hline Religious fundamentalism & 0.19 & 0.39 & .02 & .02 & .04 & $.07^{* *}$ \\
\hline
\end{tabular}

${ }^{*} p<.05^{* *} p<.01{ }^{* \star *} p<.001$. 
membership in a fundamentalist denomination, and is based upon self-reported religious affiliation which is then coded according to the definitions from the General Social Survey (Smith 1987). Based on prior punitiveness research (Applegate et al. 2000; Borg 1997; Grasmick and McGill 1994), we expect a positive relationship between religious fundamentalism and a punitive attitude toward the enfranchisement of exfelony offenders.

A final control variable included in our models is a measure of crime salience which is based on the following question: "Regarding your own personal safety, how safe would you say that you feel being out in your neighborhood at night?" The response categories ranging from "Very safe," to "Very unsafe" were collapsed into a dichotomous variable (Unsafe = 1) which combines "Unsafe" and "Very Unsafe." Prior research on punitive attitudes has considered fear, victim experience and general concern about crime as indicators of crime salience. Our measure of perceived safety comes closest to fear, and is sometimes called fear in the research literature. For the most part, fear has been positively related to punitiveness (Applegate et al. 2000; Langworthy and Whitehead 1986; Schwartz, Guo, and Kerbs 1993), but Cohn et al. (1991) and Hogan, Chiricos, and Gertz (2005) found this relationship only for respondents who were not white.

\section{Analytic Strategy}

The relationship between racial threat and opposition to restoring the right to vote for ex-felons is assessed using logistic regression. There are no apparent problems of multicollinearity, with tolerance levels (estimated in OLS) consistently above .85 . Separate logit models are estimated for opposition to the re-enfranchisement of those convicted of an unspecified crime, illegal stock trading, violent crime and a sex crime ${ }^{6}$. We then examine the effect of racial threat on these relationships separately for black, Hispanic and white respondents, before considering several contextual circumstances that may specify the conditional nature of these effects.

\section{RESEARCH FINDINGS}

Table 2 presents the results of four logit models estimating the effects of the racial typification of crime,

\footnotetext{
${ }^{6}$ In addition to the logistic models with dichotomous dependent variables, we estimated ordered multinomial logistic regression models for the four crime types and the results were substantively unchanged.
}

perceived racial composition, and a number of control variables on opposition to the re-enfranchisement of ex-felons. These data show that those who are generally more punitive (Punitiveness) are consistently opposed to restoring ex-felon voting rights, regardless of the type of offender involved. Political conservatives are more likely to oppose re-enfranchisement for each offender type except those convicted of illegal trading of stocks. Older respondents are more likely to oppose giving back the right to vote in general - for those convicted of an unspecified crime-but age is not significant in estimates for the specific criminal types indicated.

With regard to racial threat, it is apparent that the perceived racial composition of neighborhood is unrelated to attitudes about re-enfranchisement, regardless of the criminal type involved. However, the more that respondents equate criminal activity with African Americans-the racial typification of crime-the more they oppose the restoration of voting rights for exfelons. This relationship is statistically significant however, only in reference to those convicted of an unspecified crime and those convicted of a violent offense, the two types of offending likely most equated with blacks (Chiricos et al. 2004). The fact that the racial typification of crime has a significant effect on attitudes toward voting rights, after controlling for additional related predictors, is evidence of a perceived race- and crime-specific threat that manifests itself in attitudes relating to the political process that go beyond attitudes toward criminal justice.

In prior research into punitive attitudes, when race mattered, those attitudes were consistently harsher among white respondents (Barkan and Cohn 2005; Borg 1997; Chiricos et al. 2004). In addition, perceived racial threat is generally understood as more characteristic of whites. For those reasons, we assess the relationship between the racial typification of crime and opposition to the re-enfranchisement of ex-felons in separate logit models for black, Hispanic and white respondents. Table 3 presents the results of those estimates which use the same predictors constituting the models shown in Table 2. For parsimony of presentation, only the coefficients for racial typification of crime are shown. Results for the full models are available on request.

The results in Table 3 show that the racial typification of crime has no significant consequence for attitudes toward voting rights among black respondents, regardless of criminal type. It should be 
Table 2: The Effect of the Racial Typification of Crime on Opposition to the Re-Enfranchisement of Ex-Felons

\begin{tabular}{|c|c|c|c|c|}
\hline & Any Felony Offender & $\begin{array}{l}\text { Illegal Trading } \\
\text { Offender }\end{array}$ & Violent Offender & Sex Offender \\
\hline Variables & $\begin{array}{l}\text { LOGIT } \\
\text { (SE) }\end{array}$ & $\begin{array}{l}\text { LOGIT } \\
\text { (SE) }\end{array}$ & $\begin{array}{l}\text { LOGIT } \\
\text { (SE) }\end{array}$ & $\begin{array}{l}\text { LOGIT } \\
\text { (SE) }\end{array}$ \\
\hline Constant & $\begin{array}{l}-5.096^{* * *} \\
(0.638)\end{array}$ & $\begin{array}{c}-1.889^{\star \star \star} \\
(0.539)\end{array}$ & $\begin{array}{l}-2.202^{* * *} \\
(0.507)\end{array}$ & $\begin{array}{l}-0.381 \\
(0.491)\end{array}$ \\
\hline Racial typification of crime & $\begin{array}{l}4.46 \times 10^{-3 * *} \\
\left(1.43 \times 10^{-3}\right)\end{array}$ & $\begin{array}{r}1.27 \times 10^{-3} \\
\left(1.32 \times 10^{-3}\right) \\
\end{array}$ & $\begin{array}{l}3.77 \times 10^{-3 * *} \\
\left(1.26 \times 10^{-3}\right)\end{array}$ & $\begin{array}{r}2.02 \times 10^{-3} \\
\left(1.24 \times 10^{-3}\right) \\
\end{array}$ \\
\hline $\begin{array}{c}\text { Perceived racial composition of } \\
\text { neighborhood }\end{array}$ & $\begin{array}{c}0.042 \\
(0.052)\end{array}$ & $\begin{array}{c}0.008 \\
(0.048)\end{array}$ & $\begin{array}{l}-0.020 \\
(0.046)\end{array}$ & $\begin{array}{l}-0.064 \\
(0.045)\end{array}$ \\
\hline Punitiveness & $\begin{array}{l}0.707^{\star \star *} \\
(0.080)\end{array}$ & $\begin{array}{l}0.514^{\star \star *} \\
(0.070)\end{array}$ & $\begin{array}{l}0.540^{* * *} \\
(0.063)\end{array}$ & $\begin{array}{l}0.466^{\star * *} \\
(0.062)\end{array}$ \\
\hline Age & $\begin{array}{l}0.015^{* * *} \\
(0.004)\end{array}$ & $\begin{array}{c}0.001 \\
(0.004)\end{array}$ & $\begin{array}{c}0.004 \\
(0.004) \\
\end{array}$ & $\begin{array}{l}-0.004 \\
(0.003)\end{array}$ \\
\hline Hispanic & $\begin{array}{c}0.199 \\
(0.243) \\
\end{array}$ & $\begin{array}{c}0.016 \\
(0.225) \\
\end{array}$ & $\begin{array}{l}-0.225 \\
(0.210) \\
\end{array}$ & $\begin{array}{l}-0.243 \\
(0.206) \\
\end{array}$ \\
\hline Female & $\begin{array}{c}0.078 \\
(0.134) \\
\end{array}$ & $\begin{array}{l}-0.005 \\
(0.124) \\
\end{array}$ & $\begin{array}{c}0.209 \\
(0.116) \\
\end{array}$ & $\begin{array}{c}0.044 \\
(0.116) \\
\end{array}$ \\
\hline Income & $\begin{array}{l}-3.15 \times 10^{-6} \\
\left(2.27 \times 10^{-6}\right)\end{array}$ & $\begin{array}{l}-2.58 \times 10^{-6} \\
\left(2.11 \times 10^{-6}\right)\end{array}$ & $\begin{array}{l}-2.11 \times 10^{-6} \\
\left(1.97 \times 10^{-6}\right)\end{array}$ & $\begin{array}{l}-3.68 \times 10^{-6} \\
\left(1.96 \times 10^{-6}\right)\end{array}$ \\
\hline Education & $\begin{array}{c}0.022 \\
(0.028) \\
\end{array}$ & $\begin{array}{l}-0.046 \\
(0.025)\end{array}$ & $\begin{array}{l}-0.014 \\
(0.024) \\
\end{array}$ & $\begin{array}{l}-0.058^{*} \\
(0.024)\end{array}$ \\
\hline Unsafe & $\begin{array}{l}-0.286 \\
(0.187) \\
\end{array}$ & $\begin{array}{l}-0.101 \\
(0.170) \\
\end{array}$ & $\begin{array}{l}-0.110 \\
(0.159) \\
\end{array}$ & $\begin{array}{c}0.038 \\
(0.158) \\
\end{array}$ \\
\hline Political conservativism & $\begin{array}{l}0.426^{* *} \\
(0.133)\end{array}$ & $\begin{array}{c}0.230 \\
(0.125) \\
\end{array}$ & $\begin{array}{c}0.407^{\star * *} \\
(0.120)\end{array}$ & $\begin{array}{l}0.312^{* *} \\
(0.120)\end{array}$ \\
\hline
\end{tabular}

${ }^{*} p<.05{ }^{* *} p<.01{ }^{* * *} p<.001$.

Table 3: The Effect of the Racial Typification of Crime on Opposition to the Re-Enfranchisement of Ex-Felons by Race/Ethnicity of Respondent

\begin{tabular}{|c|c|c|c|c|}
\hline & Any Felony Offender & Illegal Trading Offender & Violent Offender & Sex Offender \\
\hline Variables & $\begin{array}{l}\text { LOGIT } \\
\text { (SE) }\end{array}$ & $\begin{array}{l}\text { LOGIT } \\
\text { (SE) }\end{array}$ & $\begin{array}{l}\text { LOGIT } \\
\text { (SE) }\end{array}$ & $\begin{array}{l}\text { LOGIT } \\
\text { (SE) }\end{array}$ \\
\hline $\begin{array}{l}\text { Black Respondents } \\
\qquad(\mathrm{N}=105)\end{array}$ & $\begin{array}{c}5.61 \times 10^{-3} \\
\left(5.82 \times 10^{-3}\right)\end{array}$ & $\begin{array}{l}-2.60 \times 10^{-4} \\
\left(5.12 \times 10^{-3}\right)\end{array}$ & $\begin{array}{c}3.78 \times 10^{-3} \\
\left(4.34 \times 10^{-3}\right)\end{array}$ & $\begin{array}{c}7.70 \times 10^{-4} \\
\left(4.44 \times 10^{-3}\right)\end{array}$ \\
\hline $\begin{array}{l}\text { Hispanic Respondents } \\
\qquad(\mathrm{N}=120)\end{array}$ & $\begin{array}{l}{ }^{\mathrm{a}} 1.30 \times 10^{-2 * *} \\
\left(4.83 \times 10^{-3}\right)\end{array}$ & $\begin{array}{c}3.32 \times 10^{-3} \\
\left(4.43 \times 10^{-3}\right)\end{array}$ & $\begin{array}{c}6.44 \times 10^{-3} \\
\left(4.36 \times 10^{-3}\right)\end{array}$ & $\begin{array}{l}2.27 \times 10^{-3} \\
\left(4.03 \times 10^{-3}\right)\end{array}$ \\
\hline
\end{tabular}

${ }^{*} \mathrm{p}<.05^{* *} \mathrm{p}<.01{ }^{* * *} \mathrm{p}<.001$.

${ }^{\mathrm{a}}$ Coefficient is significantly different from that for White Respondents $(p<.05)$.

noted however, that several of the regression coefficients for black respondents are actually higher than for Hispanics and whites, but the small number of
African Americans in the sample likely precludes statistical significance. Among Hispanics, opposition to the re-enfranchisement of ex-felons is elevated by the 
perception that crime is more characteristic of blacks, but this relationship achieves statistical significance only for the unspecified offender category and for none of the specific crime types. In general, the coefficients for Hispanic respondents are stronger than for the other two groups, but the restricted numbers of Hispanic respondents likely contributes to the lack of statistical significance within the violent ex-felon category. For white respondents, opposition to the reenfranchisement of ex-felons is raised by the racial typification of crime, but that relationship is significant only for the general crime and violent crime categories. Given the predominance of whites in our sample, the correspondence of these results with those in Table 2 for the full sample is not surprising. Tests for the significance of slope differences, using Allison's (1999) approach for logit coefficients, show the only significant disparity to be that between Hispanic and white respondents for the "any felony offender" category.

As noted earlier, a recent study of racial typification and punitive attitudes found that the relationship was contextually variable (Chiricos et al. 2004). It was usually stronger in those contexts that were generally less punitive (e.g. non-southern, less racially prejudiced, less concerned about crime) suggesting a "ceiling effect" in those contexts that were more punitive. We take a similar approach to assess the potentially contextual nature of these relationships and in doing so, we use the variables that had a significant effect on opposition to re-enfranchisement in the full sample estimates from Table 2 to specify those contexts. These are Punitiveness, Conservatism and Age. Models for each offender type are estimated for sub-sample contexts of conservative vs. liberal/moderate and using median values, older vs. younger and higher vs. lower punitiveness ${ }^{7}$. These models are the same as those shown in Table 2, except for the elimination of the Black and Hispanic variables-the small $n$-size for black and Hispanic respondents limits these and subsequent analyses to white respondents-and the particular variable used to specify context.

\footnotetext{
${ }^{7}$ We initially examined interaction terms involving racial typification of crime and punitiveness, age and political ideology respectively. Only that involving punitiveness for the unspecified criminal category was significant. Sub-sample analysis affords two pieces of useful information that interaction terms do not. First, it lets us assess the magnitude of the relationship of interest separately for different types of respondents and it lets us see whether that relationship retains significance across different sub-samples. Since this is the first ever assessment of this specific research question, we considered it worth exploring the issues of context beyond what interaction terms alone would allow.
}

Table 4 shows the results of these contextual analyses. Again, we only show coeffcients for the racial typification of crime variable in the several contexts examined. Full model estimates are available on request. The data in Table 4 show that the effects of racial typification of crime on opposition to reenfranchisement are consistently greater for those who score lower on the general punitiveness measure. This effect of racial threat is significant for the unspecified and violent offender categories. The difference between high and low punitiveness in the effect of racial typification on opposition to re-enfranchisement is significant for the unspecified offender category. This is the only significant slope difference between contextual categories in Table 4.

Among older respondents, racial typification significantly predicts opposition to felon reenfranchisement in the unspecified and violent offender categories, but the difference between older and younger respondents in this regard is significant only for the unspecified offender category. The linking of crime with blacks enhances opposition to ex-felon voting rights more among liberals and moderates than among conservatives. However this effect is significant only for violent offenders, for whom the difference between contexts of political ideology is also significant.

The findings of greater racial threat effects within generally less punitive individual level contexts (low punitiveness, liberal/moderate) are consistent with what Chiricos et al. (2004) report in their study of racial typification and punitive attitudes. The contextual results involving age are not. While Table 2 showed that older respondents were more opposed to reenfranchisement, Table 4 shows that that the effects of racial typification on that opposition is actually stronger for respondents above the median age of 53 and achieves statistical significance for the unspecified crime and violent crime categories. It should be noted however, that while the direct effects of age (Table 2) are positive, they are substantially weaker than those of Punitiveness and Conservatism and so the apparent "ceiling effect" involving those two variables may not apply to Age.

A final assessment of the potentially contextual nature of the relationship being studied makes use of aggregate as opposed to individual level contexts. The question is whether the effect of racial typification on opposition to re-enfranchisement varies for individuals living in contexts characterized by higher and lower 
Table 4: The Effect of the Racial Typification of Crime on Opposition to the Re-Enfranchisement of Ex-felons by Individual-Level Contexts (White Respondents Only)

\begin{tabular}{|c|c|c|c|c|}
\hline & Any Felony Offender & Illegal Trading Offender & Violent Offender & Sex Offender \\
\hline & $\begin{array}{l}\text { LOGIT } \\
\text { (SE) }\end{array}$ & $\begin{array}{l}\text { LOGIT } \\
\text { (SE) }\end{array}$ & $\begin{array}{l}\text { LOGIT } \\
\text { (SE) }\end{array}$ & $\begin{array}{c}\text { LOGIT } \\
\text { (SE) }\end{array}$ \\
\hline \multicolumn{5}{|l|}{ Punitiveness } \\
\hline High & $\begin{array}{c}0.151 \\
(0.195)\end{array}$ & $\begin{array}{c}0.047 \\
(0.188)\end{array}$ & $\begin{array}{c}0.167 \\
(0.194)\end{array}$ & $\begin{array}{c}0.122 \\
(0.192)\end{array}$ \\
\hline Low & $\begin{array}{c}{ }^{\mathrm{a}} 0.922^{\star *} \\
(0.316)\end{array}$ & $\begin{array}{c}0.326 \\
(0.268)\end{array}$ & $\begin{array}{l}0.527^{*} \\
(0.230)\end{array}$ & $\begin{array}{c}0.355 \\
(0.227)\end{array}$ \\
\hline \multicolumn{5}{|l|}{ Age } \\
\hline Older & $\begin{array}{l}0.583^{\star *} \\
(0.207)\end{array}$ & $\begin{array}{c}0.311 \\
(0.195)\end{array}$ & $\begin{array}{l}0.437^{*} \\
(0.188)\end{array}$ & $\begin{array}{c}0.278 \\
(0.186)\end{array}$ \\
\hline Younger & $\begin{array}{l}-0.038 \\
(0.286)\end{array}$ & $\begin{array}{l}-0.137 \\
(0.256)\end{array}$ & $\begin{array}{c}0.159 \\
(0.242)\end{array}$ & $\begin{array}{c}0.144 \\
(0.239)\end{array}$ \\
\hline \multicolumn{5}{|l|}{ Political Ideology } \\
\hline Conservative & $\begin{array}{c}0.234 \\
(0.240)\end{array}$ & $\begin{array}{c}0.050 \\
(0.233)\end{array}$ & $\begin{array}{l}-0.108 \\
(0.235)\end{array}$ & $\begin{array}{c}0.086 \\
(0.234)\end{array}$ \\
\hline Liberal/Moderate & $\begin{array}{c}0.419 \\
(0.232)\end{array}$ & $\begin{array}{c}0.166 \\
(0.207)\end{array}$ & $\begin{array}{l}0.629^{* *} \\
(0.196)\end{array}$ & $\begin{array}{c}0.304 \\
(0.191)\end{array}$ \\
\hline
\end{tabular}

${ }^{*} \mathrm{p}<.05^{* *} \mathrm{p}<.01{ }^{* * *} \mathrm{p}<.001$

${ }^{a}$ Difference in coefficients is statistically significant at $p<.05$.

levels of what is presumed to be racial threat. The aggregate indicators of racial threat used here are percent black of respondent's zip code and the percent of prison admissions from respondent's county that are black.

Both Preuhs (2001) and Behrens et al. (2003) found that minority composition of states' prison populations helped account for variation in felon disenfranchisement legislation. For our purposes, prison admissions were thought to capture the more immediate race/convict context in counties than prison populations which involve accrued circumstances over long periods of time-especially given the length of prison sentences in the past decade or two. Behrens et al. (2003) also report an effect of percent black of the general population on such legislation and as noted previously, percent black has been frequently used as a measure of racial threat itself. We aggregate this variable at the zip-code level to provide a more proximate indicator of potential threat than would be true of county-level data.

Table 5: The Effect of the Racial Typification of Crime on Opposition to the Re-Enfranchisement of Ex-Felons by Community-Level Contexts (White Respondents Only)

\begin{tabular}{|c|c|c|c|c|}
\hline & Any Felony Offender & Illegal Trading Offender & Violent Offender & Sex Offender \\
\hline & $\begin{array}{l}\text { LOGIT } \\
\text { (SE) }\end{array}$ & $\begin{array}{l}\text { LOGIT } \\
\text { (SE) }\end{array}$ & $\begin{array}{l}\text { LOGIT } \\
\text { (SE) }\end{array}$ & $\begin{array}{l}\text { LOGIT } \\
\text { (SE) }\end{array}$ \\
\hline \multicolumn{5}{|c|}{ Zip Code Percent Black } \\
\hline High & $\begin{array}{c}0.299 \\
(0.219)\end{array}$ & $\begin{array}{l}-0.028 \\
(0.206)\end{array}$ & $\begin{array}{l}0.399^{*} \\
(0.200)\end{array}$ & $\begin{array}{c}0.174 \\
(0.198)\end{array}$ \\
\hline Low & $\begin{array}{l}0.468^{+} \\
(0.253)\end{array}$ & $\begin{array}{l}0.412^{+} \\
(0.234)\end{array}$ & $\begin{array}{c}0.253 \\
(0.223)\end{array}$ & $\begin{array}{c}0.272 \\
(0.220)\end{array}$ \\
\hline \multicolumn{5}{|c|}{ County Black Prison Admission Rate } \\
\hline High & $\begin{array}{l}0.438^{+} \\
(0.246)\end{array}$ & $\begin{array}{c}0.084 \\
(0.221)\end{array}$ & $\begin{array}{l}0.576^{\star *} \\
(0.219)\end{array}$ & $\begin{array}{c}0.298 \\
(0.212)\end{array}$ \\
\hline Low & $\begin{array}{c}0.354 \\
(0.225)\end{array}$ & $\begin{array}{c}0.250 \\
(0.215)\end{array}$ & $\begin{array}{c}0.095 \\
(0.205)\end{array}$ & $\begin{array}{c}0.135 \\
(0.205)\end{array}$ \\
\hline
\end{tabular}

${ }^{+} p<.10{ }^{*} p<.05^{* *} p<.01{ }^{* \star *} p<.001$. 
Following the same strategy outlined for individual level contexts, we show the coefficients for racial typification of crime from logit estimates of opposition to re-enfranchisement using the same variables as described for Table 4. The results are displayed in Table 5. There are no significant differences between contexts of higher and lower racial threat involving either percent black or percent black of prison admissions. Nor are there any consistent patterns of stronger or weaker relationships between racial typification and opposition to ex-felon voting rights. However, for violent offenders, that relationship is statistically significant in the high threat context for both threat indicators. In brief, there is little to be said about the relevance of racial threat at the aggregate level for the issue being examined here.

\section{CONCLUSION}

It has been previously found that both the enactment and severity of felon disenfranchisement laws are related to several indicators of racial threat (Hull 2006; Manza and Uggen 2006; Preuhs 2001). The present research adds another dimension to the link between racial threat and denial of the right to vote. In Florida, a state with almost half of the nation's disenfranchised ex-felons (Manza and Uggen 2006:249-250), popular opposition to their reenfranchisement is positively related to perceived racial threat. Specifically, the more that individuals associate crime with African Americans, the stronger their opposition to restoring voting rights for ex-felons who have completed their sentence and are living in the community. Among whites, this opposition is statistically significant with regard to unspecified criminal offenders and to violent criminals in particular but not with regard to those convicted of illegal stock transactions or sex offenses. For Hispanics, this relationship is significant only for unspecified criminals. The fact that these relationships are generally unaffected by contextual interactions at the individual and aggregate levels, underscores their overall robustness. The exceptions using the individual level contexts of general punitiveness and conservatism are consistent with a similar finding involving racial typification of crime and support for punitive measures reported by Chiricos et al. (2004), which was interpreted in terms of a ceiling effect.

It appears then, that racial threat is limited in its relevance here to unspecified criminals in general and to violent criminals in particular. While the racial typification of crime does increase opposition to restoring voting rights for illegal stock traders and sex criminals, these relationships lack statistical significance. The reasons why, can only be conjectured. For stock traders, racial threat may be irrelevant because respondents presume that most of these offenders are white. For sex offenders, it is possible that opposition to re-enfranchisement is sufficiently high to begin with, that racial typification of crime is simply less relevant-a ceiling effect. Comparing regression coefficients of other predictors across models for the crime types excluding stock traders (Table 2) it is apparent that even the effects of political conservatism and general punitiveness are weaker for sex offenders than for criminals in general and for violent offenders. The goodness of fit parameters for those models are also consistent with this interpretation.

These findings have several important implications. In theoretical terms, these results extend the relevance of racial threat for understanding the mobilization of social controls. It is notable that perceived racial composition of neighborhood-which has sometimes been used as a perceptual measure of racial threatwas inconsequential in these analyses. It may be, as Chiricos et al. (2004) contend, that the racial typification of crime is actually a more direct measure of perceived racial threat than the perception that substantial numbers of racial "others" live nearby. In fact, the latter assumes that racial typification of crime is true-otherwise the residential proximity of blacks would not equate to a crime threat (Pickett et al. 2012).

The linkage of racial threat, measured as the racial typification of crime, to the willingness to exclude exfelons from voting, raises an interesting issue. In light of Blalock's (1967) initial characterization of the political threat posed by minorities to a dominant majority, and the emergent concept of racial threat in criminal terms, these findings represent a seeming conflation of what could be understood as both criminal and political threat. Support for the denial of voting rights to exfelons is a sanction related to criminal threat that has the additional consequence of minimizing political threat. It is impossible to know from these data whether opposition to re-enfranchisement involves conscious motive in relation to political threat. But these data do show that the racial typification of crime enhances that opposition independent of the effects of punitiveness toward crime in general and it does so more strongly among those who are generally less punitive toward criminals. Thus future research should evaluate 
whether the effect of racial typification of crime on views about felon re-enfranchisement is limited to persons perceiving blacks to be politically threatening.

These findings also contribute to the growing body of research literature that links negative racial attitudes and perceptions to support for punitive policies toward criminals. In this regard, support for punitiveness administered directly by the criminal justice system has been linked to racial prejudice (Barkan and Cohn 1994; Johnson 2001; Soss et al. 2003; Unnever and Cullen 2010), the perception that minorities have "too many civil rights" (Rossi and Berk 1997), the belief that black juveniles are less willing to acknowledge guilt (Leiber and Woodrick 1997), the stereotyping of blacks as violent (Barkan and Cohn 2005) and the racial typification of crime (Chiricos et al. 2004; Pickett and Chiricos 2012). The present study also makes use of the racial typification of crime and adds opposition to the re-enfranchisement of ex-felons to the list of punitive impulses connected to negative racial attitudes or perceptions. As noted previously, those impulses have included support for the death penalty, spending more money to fight crime and harsher penalties for criminal offenders. Now that list of impulses includes a component of what Travis (2002:22) characterized as "civic death"-exclusion from the citizen's right to vote.

It has been noted that the establishment of barriers to the franchise in the nineteenth century was often justified by the presumed higher levels of criminality of black Americans (Uggen et al. 2003:51). It is an interesting commentary on our political culture and fabric that more than one hundred years later, the same rationale-what is called here, the racial typification of crime-is a significant basis of support for the same barriers of exclusion. And the political result is the same. Because of disproportionate representation within the "great penal gulag" (Young 1999:190) created in this country in the past twenty years, substantial numbers of African Americans are denied a basic right of citizenship and a fundamental tenet of democracy is undermined. And it is not just those specifically barred from voting who are affected. For as Manza and Uggen (2006:186) have argued, "when any group has its ballots rejected, all citizens with similar preferences suffer."

\section{ACKNOWLEDGEMENT}

The authors would like to thank Gary Kleck, Dan Mears and Patricia Warren for their helpful comments on an earlier draft of this paper.

\section{REFERENCES}

Allison, Paul D. 1999. "Comparing Logit and Probit Coefficients Across Groups." Sociological Methods Research 28(2): 186208.

http://dx.doi.org/10.1177/0049124199028002003

American Association for Public Opinion Research. 2008. Standard Definitions: Final Dispositions of Case Codes and Outcome Rates for Surveys. Ann Arbor, MI: American Association for Public Opinion Research.

Applegate, Brandon K., Francis T. Cullen, Bonnie S. Fisher, and Thomas Vander Ven. 2000. "Forgiveness and Fundamentalism: Reconsidering the Relationship Between Correctional Attitudes and Religion." Criminology 38(3): 71953.

http://dx.doi.org/10.1111/j.1745-9125.2000.tb00904.x

Barkan, Steven E., and Steven F. Cohn. 1994. "Racial Prejudice and Support for the Death Penalty by Whites." Journal of Research in Crime and Delinquency 31(2): 202-09. http://dx.doi.org/10.1177/0022427894031002007

Barkan, Steven E., and Steven F. Cohn. 2005. "Why Whites Favor Spending More Money to Fight Crime: The Role of Racial Prejudice." Social Problems 52(2): 300-14. http://dx.doi.org/10.1525/sp.2005.52.2.300

Barlow, Melissa H. 1998. "Race and the Problem of Crime in Time and Newsweek Cover Stories, 1946 to 1995." Social Justice 25(2): 149-83.

Behrens, Angela, Christopher Uggen, and Jeff Manza. 2003. "Ballot Manipulation and the 'Menace of Negro Domination': Racial Threat and Felon Disenfranchisement in the United States, 1850-2002." American Journal of Sociology 109(3): 559-605. http://dx.doi.org/10.1086/378647

Blalock, Hubert M. 1967. Toward a Theory of Minority Group Relations. New York, NY: John Wiley and Sons Publishers.

Blumstein, Albert, and Jacqueline Cohen. 1980. "Sentencing of Convicted Offenders: An Analysis of the Public's View." Law and Society Review 14(2): 223-61. http://dx.doi.org/10.2307/3053313

Borg, Marian J. 1997. "The Southern Subculture of Punitiveness? Regional Variation in Support for Capital Punishment." Journal of Research in Crime and Delinquency 34(1): 25-45. http://dx.doi.org/10.1177/0022427897034001003

Britt, Chester L. 2000. "Social Context and Racial Disparities in Imprisonment." Justice Quarterly 17(4): 707-32. http://dx.doi.org/10.1080/07418820000094731

Chiricos, Ted, Ranee McEntire, and Marc Gertz. 2001. "Perceived Racial and Ethnic Composition of Neighborhood and Perceived Risk of Crime." Social Problems 48(3): 322-40. http://dx.doi.org/10.1525/sp.2001.48.3.322

Chiricos,Ted, Kelly Welch, and Marc Gertz. 2004. "Racial Typification of Crime and Support for Punitive Measures." Criminology 42(2): 359-89.

http://dx.doi.org/10.1111/j.1745-9125.2004.tb00523.x

Cohn, Steven F., Steven E. Barkan, and William A. Halteman. 1991. "Punitive Attitudes Toward Criminals: Racial Consensus or Racial Conflict?" Social Problems 38(2): 287-96. http://dx.doi.org/10.2307/800534

Crawford, Charles, Ted Chiricos, and Gary Kleck. 1998. "Race, Racial Threat and Sentencing of Habitual Offenders." Criminology 36(3): 481-512. http://dx.doi.org/10.1111/j.1745-9125.1998.tb01256.x

Crist, Charlie. 2007. Governor Crist Announces Clemency Board's Vote to Restore Civil Rights. Press Release April 5. Available from: http://www.flgov.com/release/8776.

Graham, Amy. 2011. Governor Scott and Florida Cabinet Discuss Amended Rules of Executive Clemency. Press Release March $9 . \quad$ Available from: http://fpc.state.fl.us/PDFs/clemency_press_release.pdf. 
Grasmick, Harold G. and Anne L. McGill. 1994. "Religion, Attribution Style, and Punitiveness Toward Juvenile Offenders." Criminology 32(1): 23-46. http://dx.doi.org/10.1111/j.1745-9125.1994.tb01145.x

Hawkins, Darnell F. 1995. "Ethnicity, Race and Crime: A Review of Selected Studies." Pp. 11-45 in Ethnicity, Race and Crime: Perspectives Across Time and Place, edited by D.F. Hawkins. Albany, NY: SUNY Press.

Heumann, Milton, Brian K. Pinarie, and Thomas Clark. 2005. "Beyond the Sentence: Public Perceptions of Collateral Consequences for Felony Offenders." Criminal Law Bulletin 41(1): 14-46.

Hogan, Michael J., Ted Chiricos, and Marc Gertz. 2005. "Economic Insecurity, Blame, and Punitive Attitudes." Justice Quarterly 22(3): 392-413. http://dx.doi.org/10.1080/07418820500219144

Hull, Elizabeth A. 2006. The Disenfranchisement of Ex-felons. Philadelphia, PA: Temple University Press.

Jamieson, Kathleen H. 1992. Dirty Politics: Deception, Distraction and Democracy. New York, NY: Oxford University Press.

Johnson, Devon. 2001. "Punitive Attitudes Toward Crime: Economic Insecurity, Racial Prejudice or Both?" Sociological Focus 34(1): 33-54.

Langworthy, Robert H., and John T. Whitehead. 1986. "Liberalism and Fear as Explanations of Punitiveness." Criminology 24(3): 575-91.

http://dx.doi.org/10.1111/j.1745-9125.1986.tb00391.x

Lavrakas, Paul J. 1993. Telephone Survey Methods: Sampling, Selection, and Supervision. $2^{\text {nd }}$ edition. Beverly Hills, CA: Sage Publications.

Leiber, Michael J., and Anne C. Woodrick. 1997. "Religious Beliefs, Attributional Styles and Adherence to Correctional Orientations." Criminal Justice and Behavior 24(4): 495-511. http://dx.doi.org/10.1177/0093854897024004006

Liska, Allen E. 1992. "Introduction to the Study of Social Control." Pp. 1-31 in Social Threat and Social Control, edited by A.E. Liska. Albany, NY: SUNY Press.

Liska, Allen E., and Mitchell B. Chamlin. 1984. "Social Structure and Crime Control Among Macrosocial Units." American Journal of Sociology 90(2): 383-95. http://dx.doi.org/10.1086/228084

Manza, Jeff, and Christopher Uggen. 2006. Locked Out: Felon Disenfranchisement and American Democracy. New York, NY: Oxford University Press. http://dx.doi.org/10.1093/acprof:oso/9780195149326.001.000 1

Manza, Jeff, Clem Brooks, and Christopher Uggen. 2004. "Public Attitudes Toward Felon Disenfranchisement in the United States." Public Opinion Quarterly 68(2): 275-86. http://dx.doi.org/10.1093/poq/nfh015

Mauer, Marc, and Meda Chesney-Lind, eds. 2002. Invisible Punishment: The Collateral Consequences of Mass Imprisonment. New York, NY: The New York Press.

Mendelberg, Tali. 1997. "Executing the Hortons: Racial Crime in the 1988 Presidential Campaign." Public Opinion Quarterly 61(1): 134-57.

http://dx.doi.org/10.1086/297790

Miller, Joann. L., Peter H. Rossi, and Jon E. Simpson. 1991. "Felony Punishments: A Factorial Survey of Perceived Justice in Criminal Sentencing." 82(2): 396-422.

Pickett, Justin T., and Ted Chiricos. 2012. "Controlling Other People's Children: Racialized Views of Delinquency and Whites' Punitive Attitudes Toward Juvenile Offenders." Criminology 50(3): 673-710.

Pickett, Justin T., Ted Chiricos, Kristin M. Golden, and Marc Gertz. 2012. "Reconsidering the Relationship Between Perceived Neighborhood Racial Composition and Whites' Perceptions of Victimization Risk: Do Racial Stereotypes Matter?" Criminology 50(1): 145-86.

http://dx.doi.org/10.1111/j.1745-9125.2011.00255.x

Pinaire, Brian, Milton Heumann, and Laura Bilotta. 2003. "Barred from the Vote: Public Attitudes Toward the Disenfranchisement of Felons." Fordham Urban Law Journal 30(5): 1519-50.

Preuhs, Robert R. 2001. "State Felon Disenfranchisement Policy." Social Science Quarterly 82(4): 733-48. http://dx.doi.org/10.1111/0038-4941.00056

Rossi, Peter H., and Richard A. Berk. 1997. Just Punishments: Federal Guidelines and Public Views Compared. New York, NY: Aldine De Gruyter.

Russell, Katheryn K. 1998. The Color of Crime. New York, NY: New York University Press.

Sandys, Marla, and Edmund F. McGarrell. 1995. "Attitudes Toward Capital Punishment: Preference for the Penalty or Mere Acceptance?" Journal of Research in Crime and Delinquency 32(2): 191-213. http://dx.doi.org/10.1177/0022427895032002004

Schwartz, Ira M., Shenyang Guo, and John J. Kerbs. 1993. "The Impact of Demographic Variables on Public Opinion Regarding Juvenile Delinquency: Implications for Public Policy." Crime and Delinquency 39(1): 5-28. http://dx.doi.org/10.1177/0011128793039001002

Skogan, Wesley G. 1995. "Crime and the Racial Fears of White Americans." Annals of the American Academy of Political and Social Science 539(1): 59-71. http://dx.doi.org/10.1177/0002716295539001005

Smith, Tom W. 1987. "Classifying Protestant Denominations." General Social Survey Methodological Report No. 43. Chicago, IL: National Opinion Research Center.

Soss, Joe, Laura Langbein, and Alan R. Metelko. 2003. "Why do White Americans Support the Death Penalty?" Journal of Politics 65(2): 397-421.

Stolzenberg, Lisa, Stewart J. D’Alessio, and David Eitle. 2004. "A Multi-Level Test of Racial Threat Theory." Criminology 42(3): 673-98.

http://dx.doi.org/10.1111/j.1745-9125.2004.tb00533.x

Szykowny, Rick. 1994. "No Justice, No Peace: An Interview with Jerome Miller." The Humanist January/February: 9-19.

Taylor, Ralph B., and Jeanette Covington. 1993. "Community Structural Change and Fear of Crime." Social Problems 40(3): 374-95. http://dx.doi.org/10.2307/3096886

Travis, Jeremy. 2002. "Invisible Punishment: An Instrument of Social Exclusion." Pp. 15-36 in Invisible Punishment: The Collateral Consequences of Mass Imprisonment, edited by M. Mauer and M. Chesney-Lind M. New York, NY: The New Press.

Uggen, Christopher, and Jeff Manza. 2002. "Democratic Contraction? Political Consequences of Felon Disenfranchisement in the United States." American Sociological Review 67(6): 777-803. http://dx.doi.org/10.2307/3088970

Uggen, Christopher, Jeff Manza, and Angela Behrens. 2003. "Felony Voting Rights and the Disenfranchisement of African Americans." Souls 5(3): 48-57.

Ulmer, Jeffrey T., and Brian Johnson. 2004. "Sentencing in Context: A Multi-Level Analysis." Criminology 42(1): 137-77. http://dx.doi.org/10.1111/j.1745-9125.2004.tb00516.x

Unnever, James D., and Francis T. Cullen. 2007. "The Racial Divide in Support for the Death Penalty: Does White Racism Matter?" Social Forces 85(3): 1281-1301. http://dx.doi.org/10.1353/sof.2007.0058

Unnever, James D., and Francis T. Cullen. 2010. "The Social Sources of Americans' Punitiveness: A Test of Three Competing Models." Criminology 48(1): 99-130. http://dx.doi.org/10.1111/j.1745-9125.2010.00181.x 
Unnever, James D., and Francis T. Cullen. 2012. "White Perceptions of Whether African Americans are Prone to Violence and Support for the Death Penalty." Journal of Research in Crime and Delinquency. Published online before print. Available from: http://jrc.sagepub.com/content/ early/2011/08/09/0022427811415533.abstract.

U.S. Department of Justice. 2005. Crime in the United States, 2004. Washington, D.C.: U.S. Government Printing Office.
U.S. Department of Justice. 2006. Criminal Victimization in the United States, 2004, Statistical Tables. Washington, D.C.: U.S. Government Printing Office.

Warner, Barbara D. 1992. "The Reporting of Crime: A Missing Link in Conflict Theory." Pp. 71-88 in Social Threat and Social Control, edited by A.E. Liska. Albany, NY: SUNY Press.

Young, Jock. 1999. The Exclusive Society. London: Sage Publications, Ltd.

Received on 22-07-2012

Accepted on 20-09-2012

Published on 03-10-2012

DOI: http://dx.doi.org/10.6000/1929-4409.2012.01.2

(C) 2012 Chiricos et al.; Licensee Lifescience Global.

This is an open access article licensed under the terms of the Creative Commons Attribution Non-Commercial License (http://creativecommons.org/licenses/by-nc/3.0/) which permits unrestricted, non-commercial use, distribution and reproduction in any medium, provided the work is properly cited. 